\title{
A GIS Approach Using Morphometric Data Analysis for the Identification of Subsurface Recent Tectonic Activity. Case Study in Quaternary Outcrops-North West of Tunisia
}

\author{
Slimene Sedrette $\mathbb{B}^{\circledR}$, Noamen Rebai \\ Geotechnical Engineering and Georisk Research Laboratory, National School of Engineering of Tunis, \\ University of Tunis El Manar, Tunis, Tunisia \\ Email: ssedrette@gmail.com
}

How to cite this paper: Sedrette, S. and Rebai, N. (2022) A GIS Approach Using Morphometric Data Analysis for the Identification of Subsurface Recent Tectonic Activity. Case Study in Quaternary Outcrops-North West of Tunisia. Journal of Geographic Information System, 14, 94-112. https://doi.org/10.4236/jgis.2022.141006

Received: January 7, 2022

Accepted: February 25, 2022

Published: February 28, 2022

Copyright () 2022 by author(s) and Scientific Research Publishing Inc. This work is licensed under the Creative Commons Attribution International License (CC BY 4.0).

http://creativecommons.org/licenses/by/4.0/

\begin{abstract}
The combination of structural and lithological data with morphometric indicators in a GIS environment constitutes a methodological approach with high added value to identify neotectonic deformations, in particular in the Quaternary outcrops where faults are generally masked by thick recent sediments. This approach, based on the crossing of multisource data, is used in this work to understand the mechanisms that generate landscape forms in the Quaternary outcrop of Oued Lahmar, which belongs to the northwest of Tunisia. In fact, the databases of various morphometric indicators, extracted from the hydrographic network, have been generated using remote sensing data and open sources applications. This database has been enriched by lithological and tectonic data extracted from the regional geological map, to understand the results of the morphometric analysis. The results obtained provide valuable information on the identification of subsurface activity in Oued Lahmar and large vicinity areas with heterogeneous geomorphic and structural characteristics. Indeed, this study revealed the existence of an E-W subsurface tectonic control covered by the Quaternary sedimentary series not indicated on the geological map of the region. This tectonic direction, which follows most of the magmatic outcrop edge in the region, may allow the intrusion of magma and the rejuvenation of ancient deep faults.
\end{abstract}

\section{Keywords}

Morphometry, GIS, Software Tools, Crossing-Data, Hydrographic Network, Oued Lahmar, Subsurface, Neotectonic 


\section{Introduction}

Since research work of Horton [1] [2] [3] concerning the study of the origin and evolution of river networks, morphometric analysis was used in several studies.

The analysis and interpretation of the morphometric indicators has been successfully applied in several studies to solve many geological problems [4] [5] [6] [7]. This analysis provides a more accurate vision of morphodynamic changes in the investigation area.

Recently, with the advancement of remote sensing and GIS, computation of various spatial data and morphometric indicators of drainage network was simplified.

The river system is a component of the complex geomorphological system, which is very sensitive to exogenous variations, including climatic variations and active tectonic deformations [8].

Changes in fluvial style, active bandwidth, river slope or the watercourse shape, may reflect a response to the tectonic activity. However, the whole network does not respond to tectonic influences in a simple and linear pattern. Higher order drains are partially adapted to the regional morphostructural organization and can be useful to highlight the regional structural pattern [9].

One of the parameters of morphostructural analysis is to detect drainage anomalies [10] and the understanding of drainage network and tectonics with the special reference to anomalies have proved their credibility beyond doubt.

Several research studies [11]-[17] have revealed that all local deviations of the drainage direction from the regional topographic gradient are treated as drainage anomalies. These drainage anomalies may have structural or lithological origins (alternating hard and soft rocks) and may be induced by erosion phenomena. Researchers [14] [17]-[23] have estimated that most of these drainage anomalies have significant neotectonics.

In Tunisia, for example, the stream network data were analyzed in southern Atlas in order to characterize the basement structure and its relationship to neotectonic evaluation [17]. In northern Tunisia, hypsometric and drainage anomaly data were used to determine the general crustal and upper-mantle structure [23] [24].

Longitudinal profiles of watercourses allow the analysis of the landscape response to internal and external perturbations. They have been widely used in studies of tectonic geo-morphology [24] [25] [26] [27] [28].

The knickpoint represents a geomorphological phenomenon characterized by an abrupt change in the slope of a watercourse. The generation and the migration of the knickpoint are closely influenced by tectonics and climate as well as the nature and hardness of the bedrock [29].

In the present study, geologic and topographic map, morphometry and remote sensing will be used to identify anomalies in the drainage network and its relationship to tectonics in the region under study. These anomalies correspond, in general, to subsurface faults and abnormal contacts. 
Various technical methods and indicators have been applied to identify the expression of major faults at different levels.

Indeed, the North African margin originated from important tectonic events, starting from the rifting phase related to the breakup of Pangea and ending with the Cenozoic Alpine orogeny of the Maghrebide chain. In Tunisia, this tectonics is reflected by intense and recent deformations, which started in the Upper Miocene and are continuing until today.

This paper uses GIS, geologic data and various morphometric indicators to present a new characterization of the subwatershed of Oued Lahmar, and to develop a more reliable information for the deep tectonic activities in the region.

\section{Materials and Methods}

\subsection{Study Area}

The study area (Figure 1), as a part of the north-west of Tunisia, belongs to the Maghreb belt in the western Mediterranean. This area resulting from the collision between the African plate (Gondwana supercontinent) and the Meso-Mediterranean microplate known as derived from the European continent during the Neo-Tethysian oceanic opening in the Lower Jurassic.

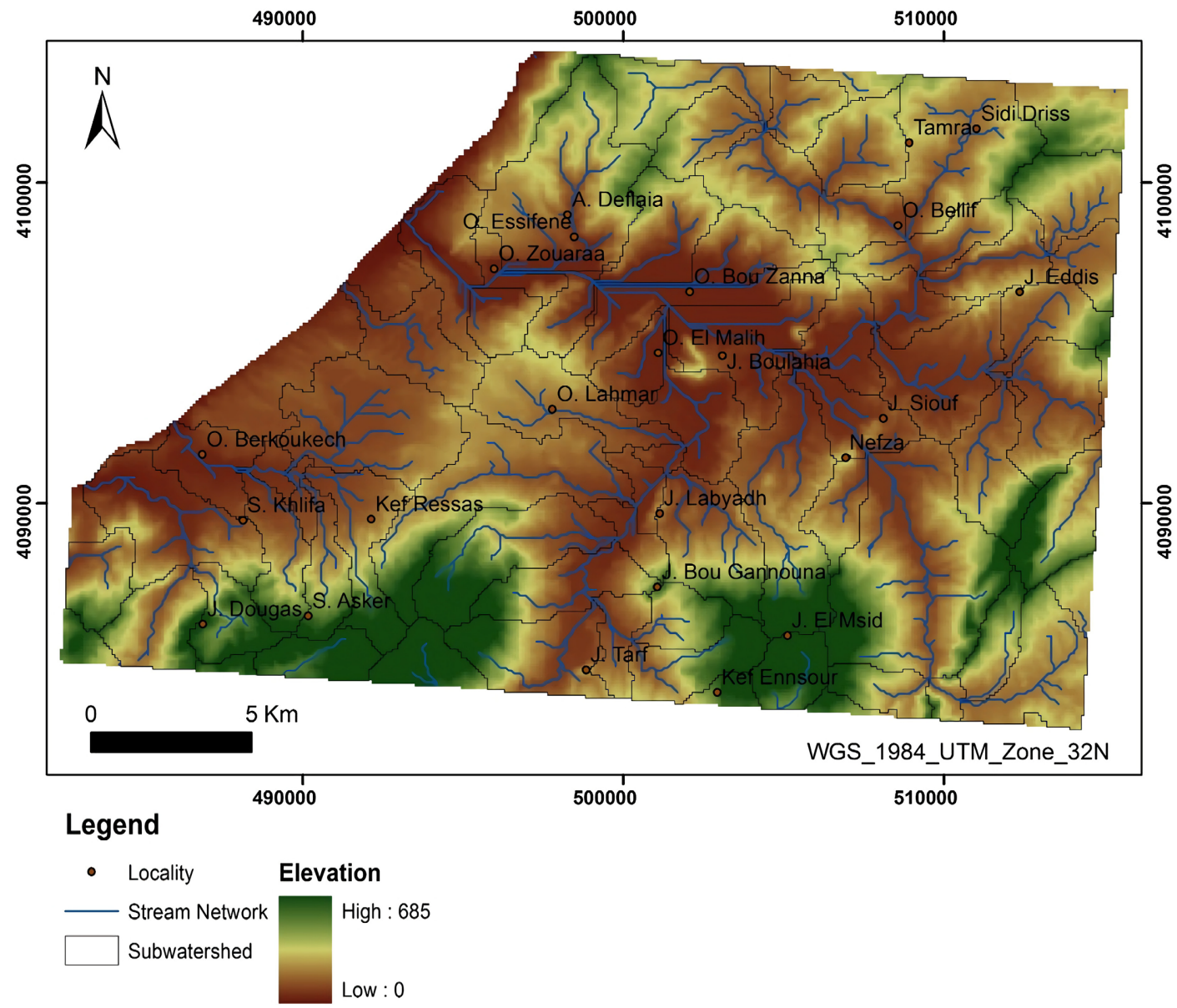

Figure 1. Digital elevation model of the study area showing hydrographic network. 
The structural organization of the region is established during the Meso-Cenozoic and Quaternary periods following a polyphase and complex geodynamic evolution.

The relatively large seismicity of northern Tunisia is the expression of an active current tectonics known so far in the foreland of the alpine chain [30] [31]. This region of the Maghreb branch belongs to the perimediterranean mobile belt, which extends from Gibraltar to the north of Calabria and is characterized by a geodynamic governed by major accidents of NW-SE to E-W and especially SWNE to N-S directions [32].

Indeed, this region is characterized by several structural features that are usually associated with the phenomena responsible for the development of polymetallic mineralization, well as the transfer and dispersion on the surface of various geochemical elements.

The landscape morphology of the region is the result of the dynamic interaction between tectonic, magmatic activity, lithology and fluvial processes [23]. Two types of relief (Figure 1) characterize the region: a mountainous area especially in the south whose highest point of elevation rises to over $685 \mathrm{~m}$ and a plain, occupying the central part of the map. The average elevation is $157 \mathrm{~m}$.

The high altitude areas are occupied by a resistant substratum represented by the Cenozoic carbonate and saliferous intrusions of Triassic age. The low slope areas are predominant and occupy mainly the beds of the Oued Zouaraa and its tributaries and the entire southwestern coastal part of the map. Sandstone and alluvial deposits mainly cover these areas.

\subsection{Geodatabase}

Recently, the use of remote sensing data and GIS provide increasingly homogeneous surface data and allow the development of more efficient processing and synthesis methods. So, the study of morphostructural characteristics and topography of a hydrographic network and its complex behavior has become possible.

In this study, the hydrographic network, automatically extracted from a $30 \mathrm{~m}$ resolution DEM (SRTM) obtained from Shuttle Radar Topography Mission data available on the United States Geological Survey (USGS) website.

The second datasets to be acquired for this study were the digital geological maps at 1:50,000 scale were imported into ArcGIS to extract the necessary geological and structural vector layer.

Geologic map, topographic map and digital radar data were geometrically rectified and georeferenced to world space coordinate system UTM (Universal Transverse Mercator)/WGS84 (World Geodetic System) using digital image processing software.

For proper determination of flow direction and flow accumulation, DEM sinks were identified and filled. To obtain the drainage basins; depressions were eliminated. The extension "Arc Hydro Tools 9.1" allows finalizing this task by using the D8 algorithm [33], a minimum accumulation area threshold was established. 
The contributing drainage area of every cell was computed and the catchments were defined and numbered to facilitate analysis.

\subsection{Drainage Anomaly Extraction}

The drainage anomaly detection can be done manually based on the hydrographic network and the relief. However, the manual aspect of this operation can be hampered by several factors including the high density of the hydrographic network, the complexity of defining the flow direction of the drains (especially in flat areas) or also the imprecision in determining the angle between surface and the drain.

In this study, in order to obtain the drainage anomaly map, the Automatic Drainage Anomalies Extraction Tool (ADAET) are used. This methodology developped by Moussi and Rebai [24] using the model builder technique in ArcGIS environment. This automatic extraction method, tested in the Enfidha area (Tunisia), can also be applied in many other areas with similar geomorphological and geological configurations: quaternary deposit plain and subsurface active faults [24].

This drainage anomalies extraction method is based on the principle that the anomalous drains correspond to the drainage flowing obliquely and deviating from the orthogonal isohypses of the summit envelope surface of the land and all those with counter slope drainage [12] [13] [14] [34].

\subsection{Knickpoint Identification}

The Neotectonics Research Group of the Federal University of Paraná has developed a tool for hydrographic network analysis and automatic knickpoint extraction based on the methods proposed by Hack [35].

This program called Knickpoint Finder, coded in python, can be easily integrated into the ArcGIS toolbox, and use a digital elevation model (DEM) as input data to identify the relief breakpoints along drainage profiles (knickpoints). This software allows the altimetric range to be determined from user-defined parameters. These parameters should be based on experience and knowledge that the user has of the analyzed area [36].

\section{Results and Discussions}

\subsection{Drainage Network Direction Analysis}

The graphical representation and spatial characterization of the drainage network is the starting point of this work, which aims to identify the subsurface activity through the automatic analysis of watersheds and river networks.

The Oued Zouaraa in the center of the map (Figure 2) collects, through its affluent Oued Bou Zanna, Oued Bellif, Oued EL Malih, and Oued Lahmar..., the waters of the North and Southeast region of the map.

The spatial distribution of the drainage network analysis, extracted from the topographic map of the study area (Figure 3(A)), shows a clear dominance of 

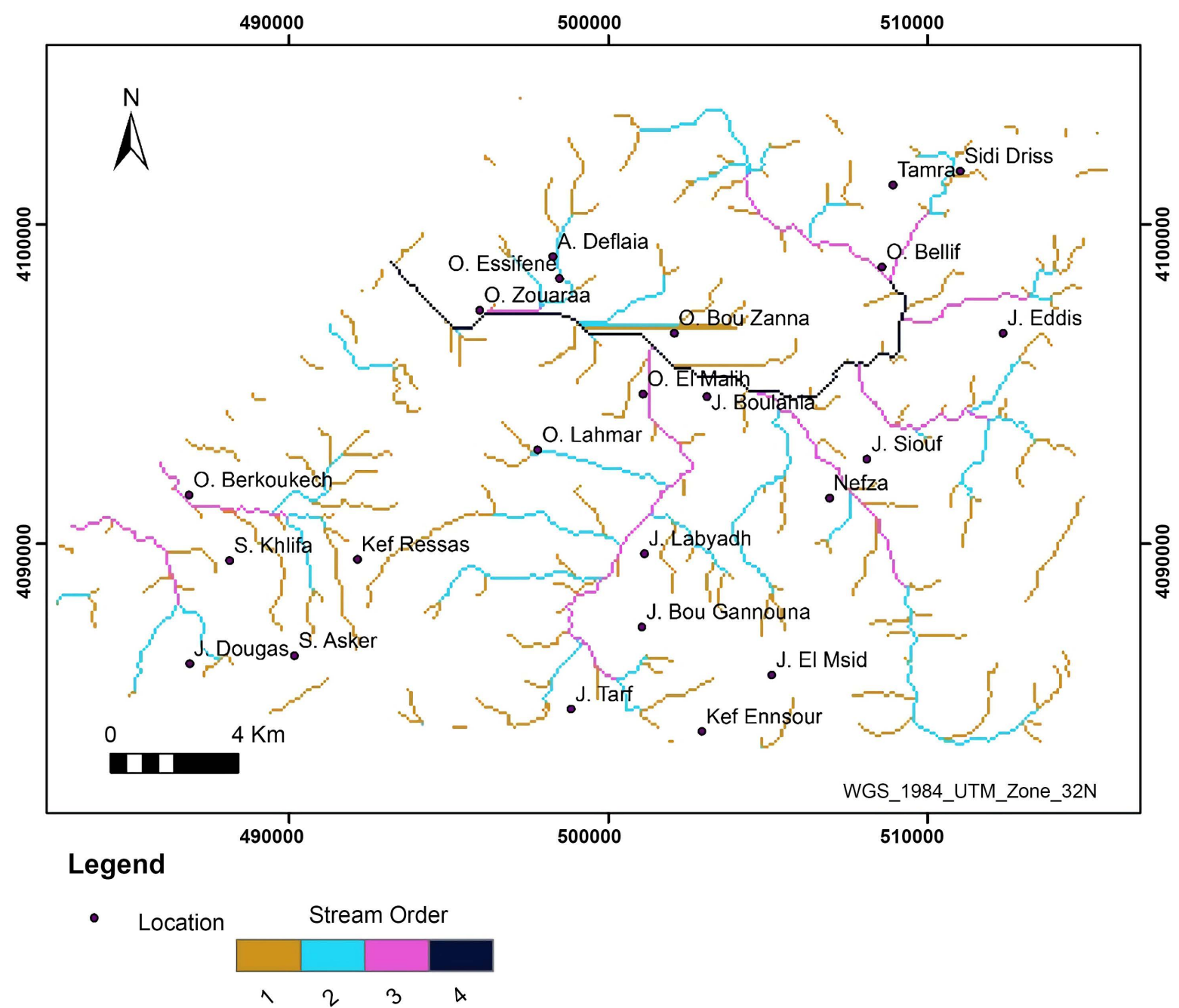

Figure 2. Spatial distribution of the drainage network order.

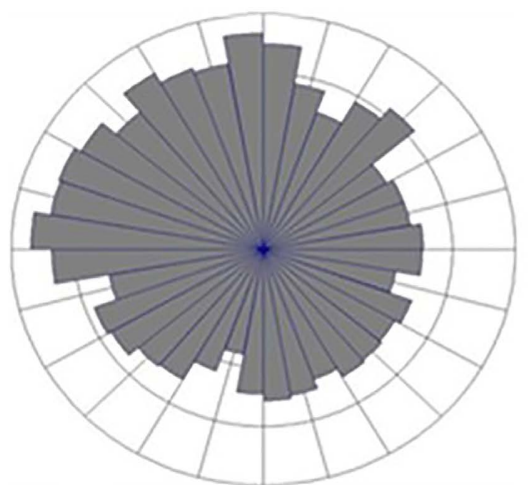

(A)

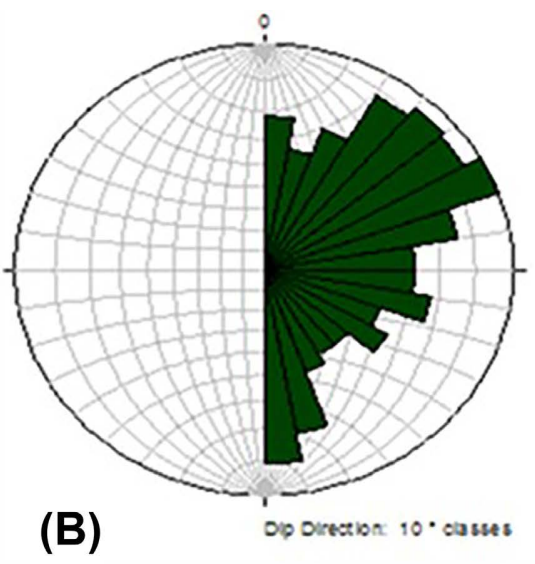

(B)

Figure 3. Rose diagrams showing directions of stream network (A) and tectonic lineaments (B).

the N-S and E-W directions succeeded respectively by the NW-SE and NE-SW directions. Indeed, statistical analysis of the tectonic lineaments extracted from 
the Nefza geological map (Figure 3(B)) shows that the major directions are N60, $\mathrm{N} 40$ and N-S respectively. The secondary order directional families are respectively NW-SE and E-W.

Therefore, we can deduce a positive correlation between the results of the structural analysis and the directions of the drainage stream. This shows the impact of the tectonic regime on the drainage network. However, the order of importance of the directional families in terms of frequency shows a clear disturbance. This modification is represented by the E-W orientation, which is the first dominant family orientation of the hydrographic network stream.

Indeed, the relationship between neotectonics and the hydrographic network seems obvious and can be seen in several study sites. This case is observed and analysed by Comentale [19] in the Matese Mountain (Italy), he shows that the inflicted neotectonics on this structure, thus generating its uplift, radically disorganized the hydrographic network.

In general, in a topographic map study, first and second order drains are often numerous, too short and too large. Riazanoff [37] explains that low-order segments (orders 1 or 2) are directly oriented in the direction of the slopes, while higher-order segments are liberated gradually from this slope effect, and their directions tend to be parallel to the major hillside slopes.

The N-S and E-W stream directions dominate the general orientations (Figure $3(\mathrm{~A})$ ) of the different stream orders. These two directions show a set with inverse evolution from lower to higher orders (Figure 4), which show high frequencies of the NE-SW and NW-SE directions and a regression of the N-S directions. The NE-SW and NW-SE directions exist whatever the order considered.
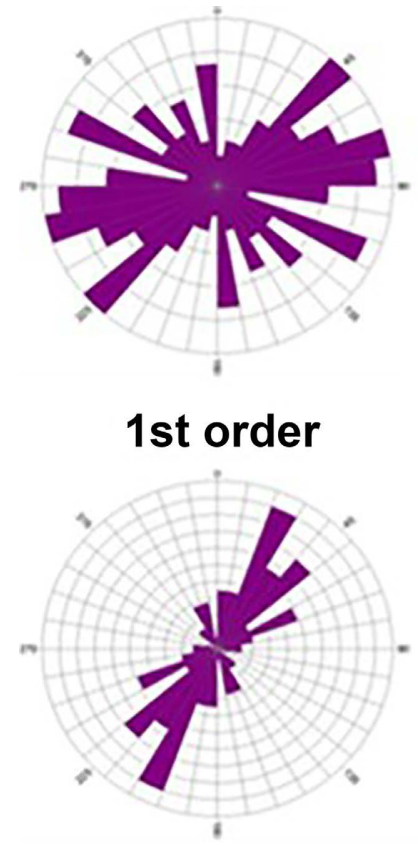

3rd order

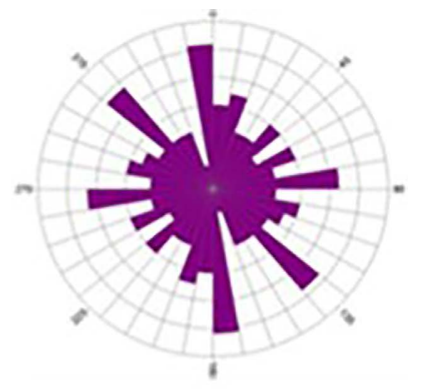

2nd order

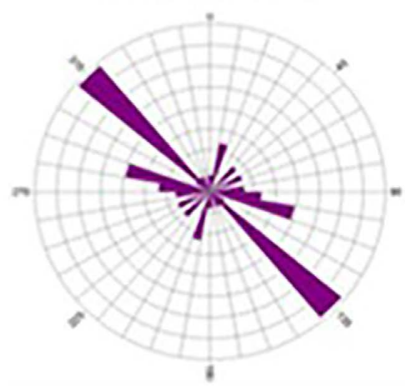

4th order

Figure 4. Rose diagrams of different order frequency of drainage network streams. 
The interpretation of the rose diagrams for different order streams (Figure $3(\mathrm{~A})$ ) and faults (Figure $3(\mathrm{~B})$ ) results in the conclusion that higher order stream, follow regional geological structures, while first order stream may be associated with notectonic structures.

\subsection{Hypsometric Analysis}

Based on the previous study conducted by Sedrette and Rebai [23] concerning the hypsometric analysis in the Nefza region, the sub-watersheds of the region can be classified into three categories, according to their hypsometric characteristics (Hypsometric Integrals (HI) and Hypsometric Curve (HC)):

- 41 basins with HI value $<0.35$ ); this watersheds are in the severe stage of erosion, with low relief (maximum threshold 35\%).

- 19 basins with $0.35<\mathrm{HI}$ value $>0.5$; this watersheds are in the intermediate stage, with moderate incision and erosion (maximum threshold 50\%).

- Basins 58, 68 and 37 with HI > 0.5 (Figure 5) characterized by a deep incision and slight soil erosion. This high HI values have generally been associated with higher rates of tectonic activity.

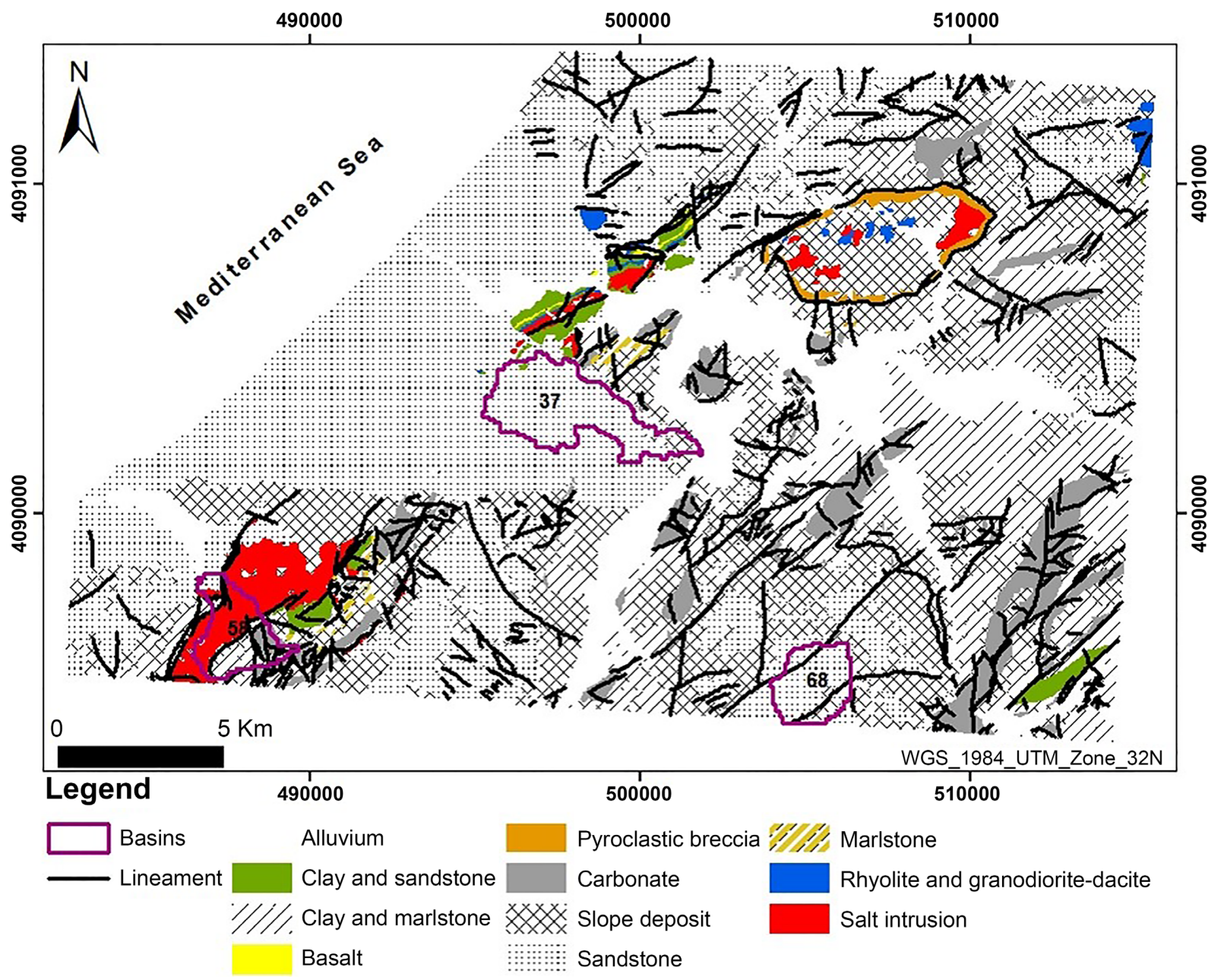

Figure 5. Geological map of Nefza region showing the distribution of sub-watershed under study. 
Indeed, basin number 58 is covered by salt-intrusion in major proportion, clay and sandstone, marlstone, sandstone, carbonate and slop deposit (Figure 5). In this case, the lithological characteristics of the land and especially the hardness of the Triassic salt-intrusion rock can be a factor to explain youthful stage of this basin.

Whereas, the both basins number 37 and 68 are covered especially by sandstone (Figure 5). For the watershed number 68 which crossed by tectonic lineaments, the high value of the $\mathrm{HI}$ and convex $\mathrm{HC}$ can be the result of active tectonics that disorganize the hydrographic network. Several studies have demonstrated the utility of hypsometric analysis in tectonic interpretation. In the active areas, the watershed hypsometric curve is S-shaped and with higher values of hypsometric integral. This reflects the constant rejuvenation of the terrain.

The Basin no 37 (Figure 6) is characterized by HI = 0.51 and S_shaped HC. The absence of apparent tectonic index in this basin does not allow explaining the results of the hypsometric analysis especially that the roofing materials are dominated by old and recent sandstone dunes. Active faults may therefore not be depicted on published geological maps, which are typically based mainly on outcrop fault mapping.

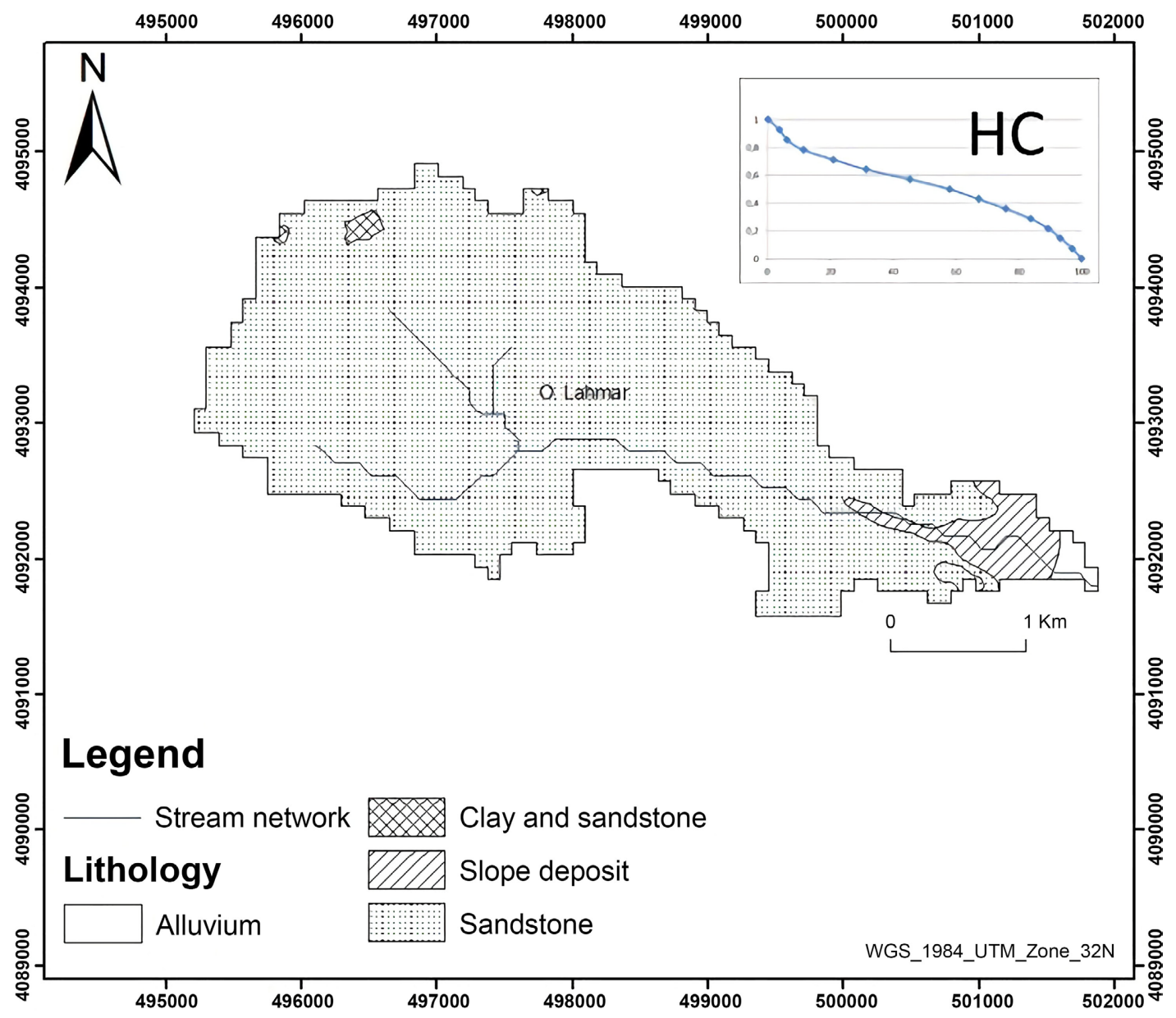

Figure 6. Sub-watershed $\mathrm{n}^{\circ} 37$ showing lithological details and hypsometric curve. 
In the eastern region of the map of Nefza, near the basin 37, which covers the Oued Lahmar and its tributaries, the hydrographic network has a low density. This area that refers to the alluvial plains of Oued Zouaraa in the North, and Oued Berkoukech in the South is covered by a permeable sandstone bedrock crossed by a few collinear subtypes streams.

\subsection{Drainage Anomaly Analysis}

The distribution of the river network extracted from the topographic Nefza map shows mainly three types of stream network pattern:

- The dendritic to contoured dendritic type characterizes mainly the NW and SW regions of the map. This type of network is superimposed on the uniformly resistant sediments, or bevelled by a horizontal surface, or crystalline rocks. A slight regional slope must have existed at the time the drainage was installed.

On the geological map of Nefza this type of network covers the Numidian sandstones.

- The trellised type characterizes the effluents of the Oued Maden at the Lower Maas-trichian carbonate rock outcropping in the south-west of the Nefza locality.

- The parallel type predominates in the north east of the map. According to Howard's definition, "it characterizes sedimentary rocks, with a clear dip, or parallel fracture zones". On the geological map, it crosses a slope formations lithology.

This allows us to deduce that the type of drainage gives an idea of the lithology and some-times of the existence of more or less intense fracturing. It is therefore a good marker of the regional geological environment.

This dendritic, parallel, and trillesid types are highly sensitive indicators of active tectonics in the deformed area [38].

If the drainage network were only directed by the topography, all drains would follow the line of greatest slope. This scheme reflects the theoretical flow pattern, which is not always the case; many networks have segments that are oblique to the normal gravity drainage or even opposite to it. The origin of these deviations from the normal is often geological.

Drainage anomalies are local course changes in the layout of the networks shape to the regional drainage, or to the topography, or to the presence of particular structures. They often highlight the existence of structural features that are usually masked.

Thus, the elaboration of the drainage anomaly map of the study area (Figure 7) shows that the overall distribution of the anomalous segments is not homogeneous, but that it favors certain directions.

In this research work, the anomalous drainage, defined by the oblique directions subject to the influence of the bedrock characteristics, allows the quantitative and qualitative study of the main directions of obstacles (Figure 8) in order to extract the most important ones. 

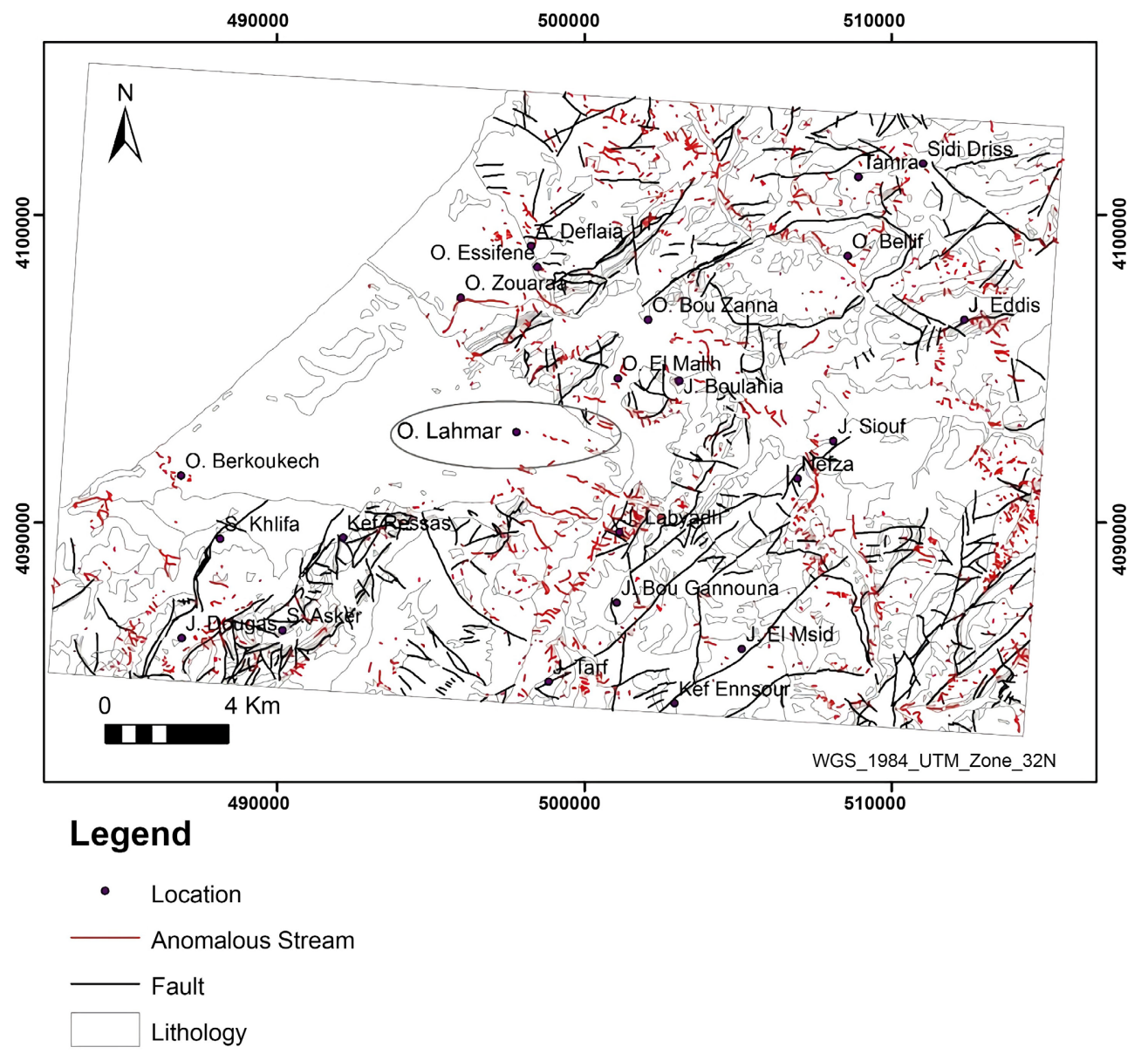

Figure 7. Simplified geological map of the study area overlaid by drainage anomaly map.

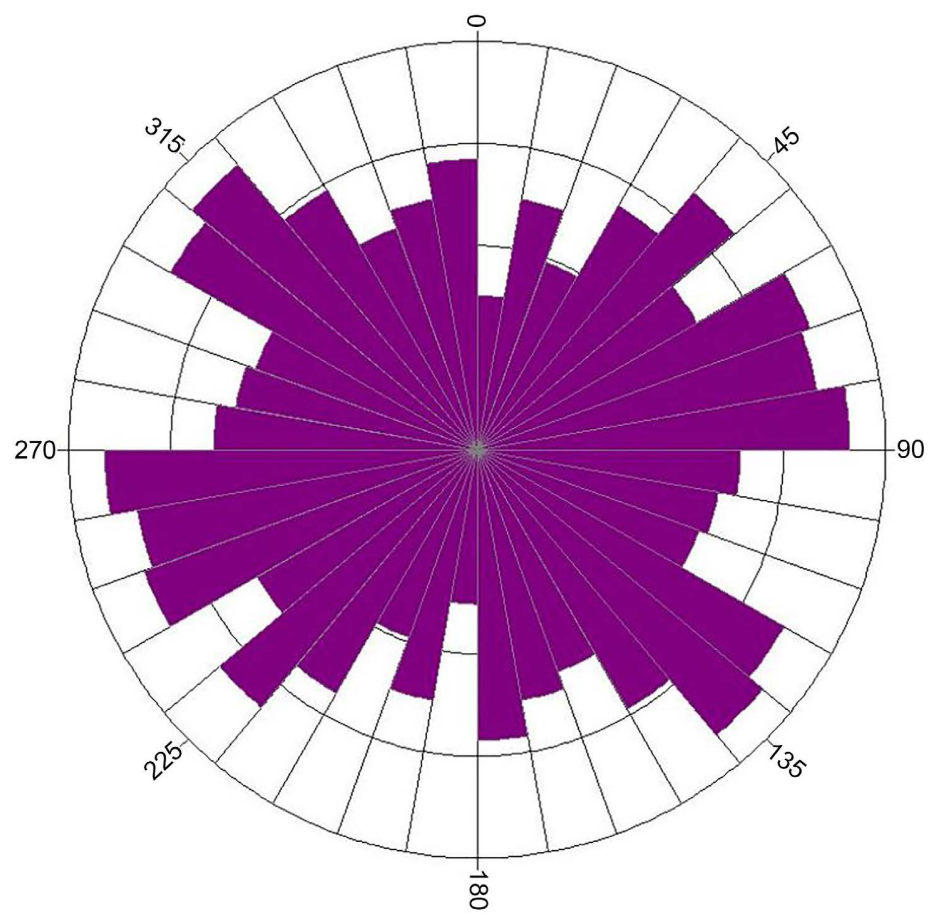

Figure 8. Rose diagram of third order anomalous drains directions. 
The statistical analysis of the anomalous segments directions (Figure 8) highlight preferential directions and reveal that the E-W, NW-SE and N-S are dominant, with a second minority mode materialized by the NE-SW direction. However, the anomalous E-W drains seem to be the majority direction family.

The results of the directional analysis of anomalous third order drain (Figure 8), show the predominance of the E-W, NW-SE and NE-SW directions respectively, while the N-S direction is insignificant.

The drainage anomalies map and its comparison with the existing tectonic and lithological map shows that parts of the drainage anomalies are located near the most important tectonic faults in the region or the result of the bedrock change with contrasting resistance to erosion.

Other drainage anomalies (marked by ellipses shape in (Figure 7)) can neither be explained by a lithological change nor by the tectonic lineament map extracted from the geological map. Their alignments indicate an EW-trending direction (Figure 9).

Knickpoints could serve as good indicators of active structures as proven in the Himalayas [39], Tibetan Plateau [40], Japan forear [41]. By applying the Knickpoint Finder in the study area, about 200 knickpoints were identified.

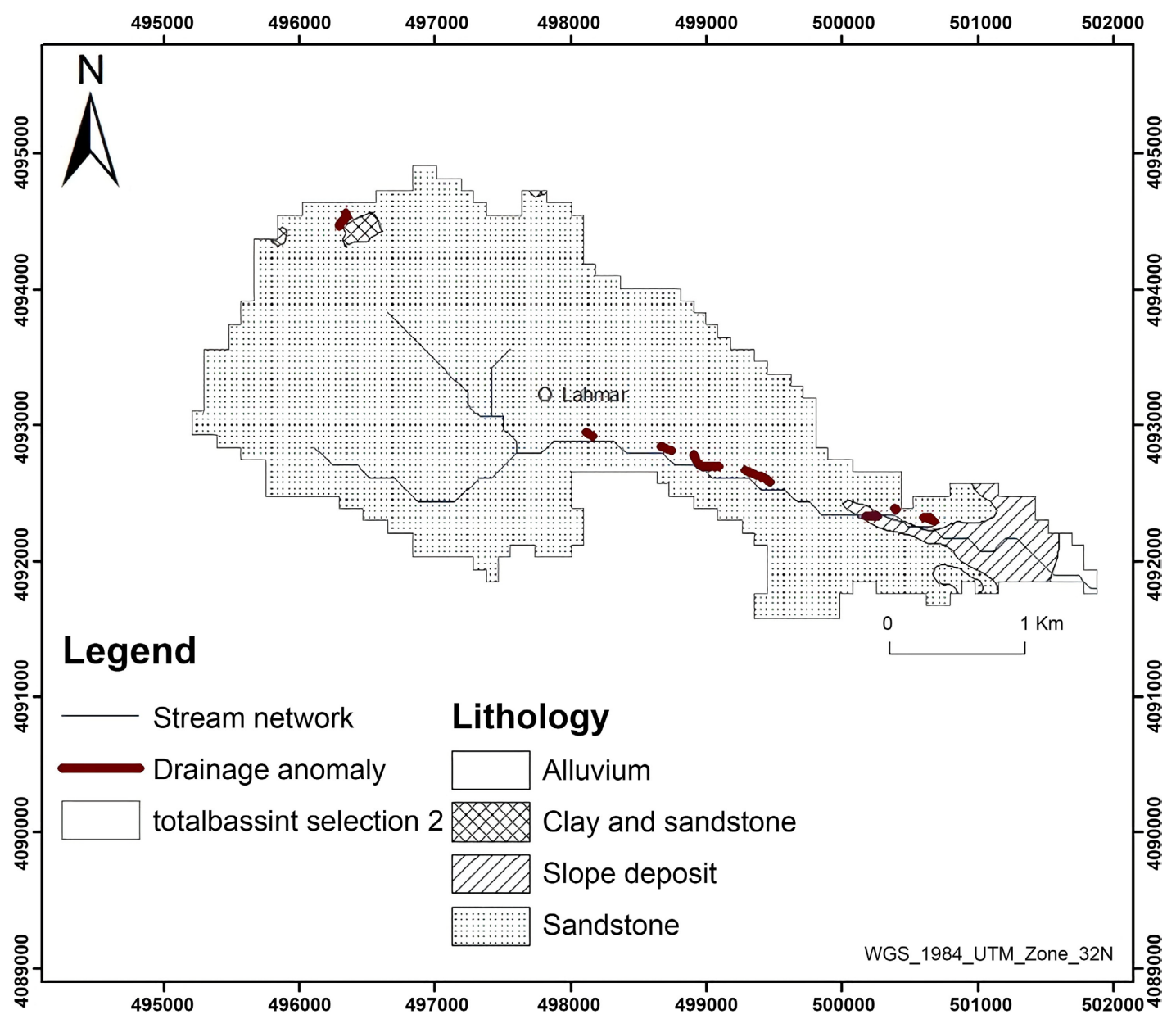

Figure 9. Drainage anomalies identified in the watercourse of Oued Lahmar. 
The superposition of the Knickpoint map on the lithological, tectonic and morphological information layers of the Nefza area was carried out in order to understand their geological significance. Most of the knickpoints, recorded along the longitudinal profiles of the various rivers in the region, are located within or around (to $0.5 \mathrm{~km}$ ) lithological boundaries, suggesting their relation to changes in rock resistance (Figure 10).

Other knickpoints are located in the proximity of tectonic discontinuities already signalled on the geological map (Figure 10). Therefore, knickpoints coinciding with the trace of these faults might be indicators of tectonic activity.

However, some knickpoint alignments their justification not explained neither by the lithology nor by the tectonic lineaments mapped on the geological map (Figure 11). One alignments of E-W anomalies can be distinguished in the area of the recent sandstone dunes in the northwestern of Oued Zouaraa.

These anomalies propagate along the Oued Lahmar, show a regressive erosion phenomenon, which induce the formation of knikpoints. These knickpoints propagate from downstream to upstream of the river as a result of a fall in the local base level facilitated by the non-cohesive structure of the sandstone rock. This alignment may be the result of tectonic uplift.

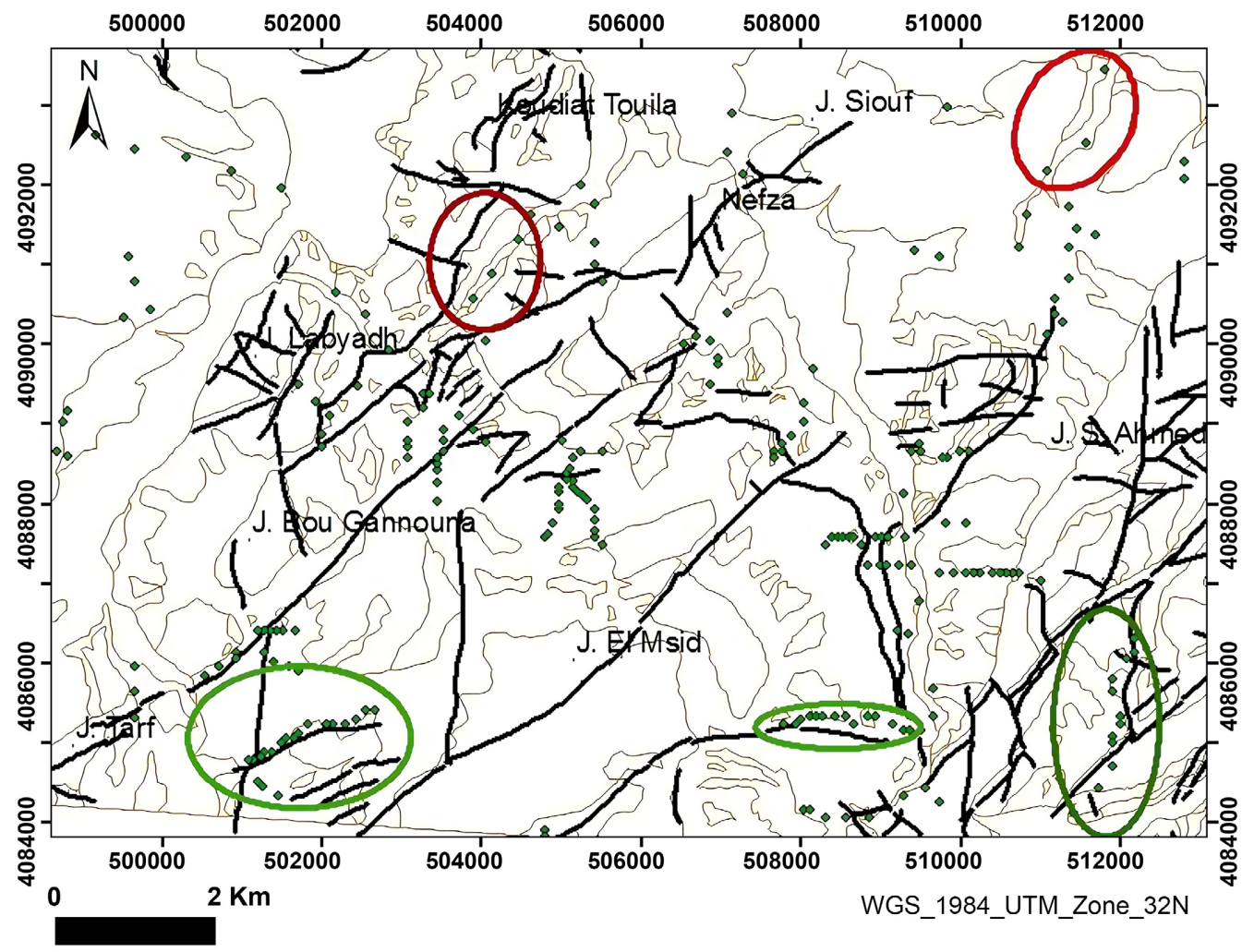

\section{Légende}

- knickpoint

_ Faille

Limite Lithologique

Figure 10. Knickpoint map surimposed with simplified geological layer. 


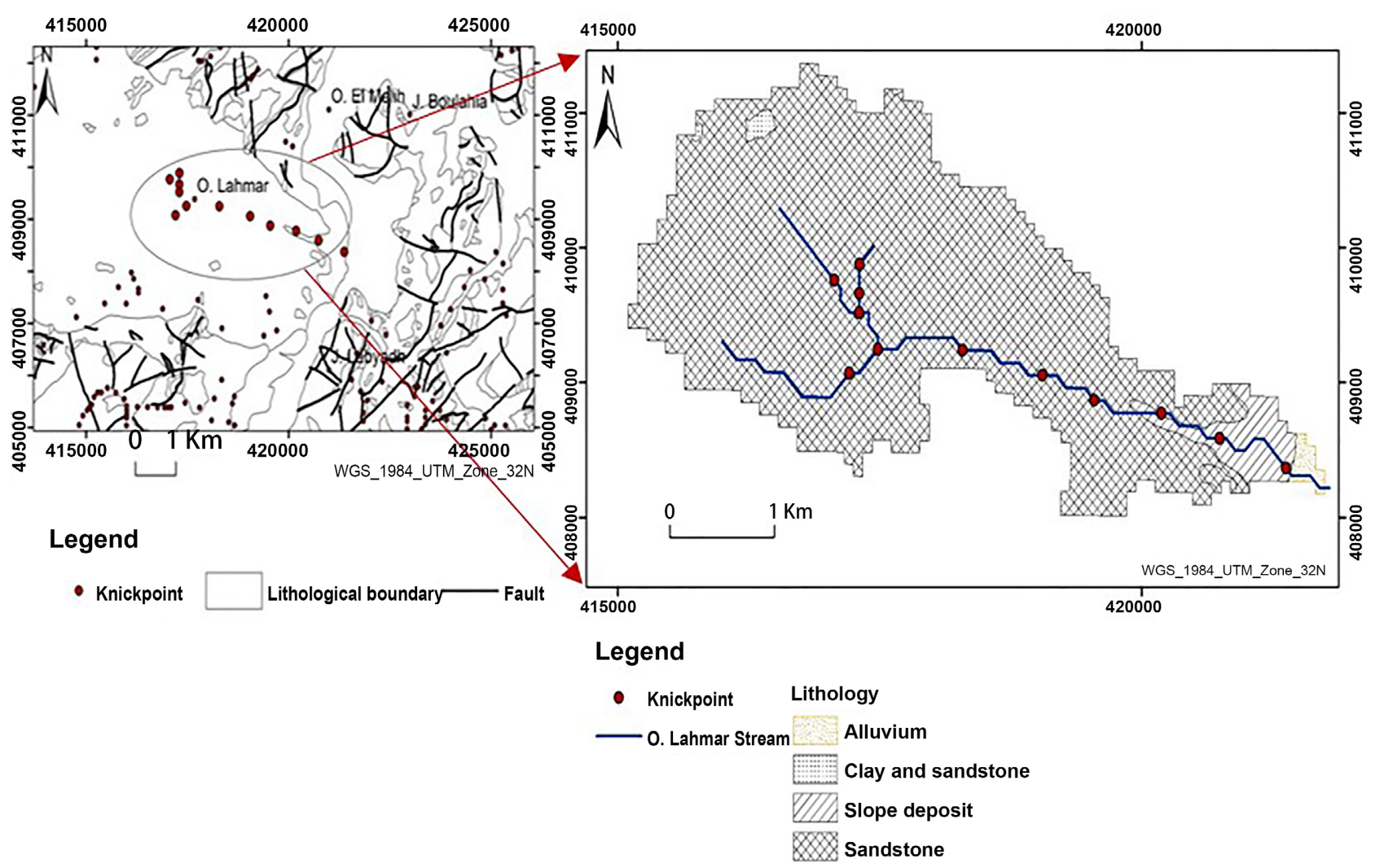

Figure 11. Knickpoint identified in the watercourse of Oued Lahmar.

In order to highlight this fact, the identification of a few points along the Oued Lahmar was carried out on site using their coordinates, extracted from the topographic layer, and a GPS device.

These knickpoints are located on Quaternary sandstone bedrock. Despite the agricultural land use, the surrounding landscape shows well-individualized terraces (Figure 12).

Such well-marked uplift by Quaternary terrace levels has also been reported in several studies [42] [43] [44] [45], that attributed this uplift to tectonic effects. However, based on the results of this morphometric study and following the overall work undertaken in the Nefza area, this terraced landscape can be interpreted as proof of epirogenic (i.e. regional) uplift, combined with the local effects of fault reactivation. This observation is also developed for other areas of the Mediterranean basin [46] [47]. Several Mediterranean river systems have been the subject of research, within the framework of the IGCP 449 project [48]. River terraces are particularly abundant in southern Italy, where they attest to an acceleration of uplift in the early Middle Pleistocene.

This observation can probably explain our hypothesis of reactivation of ancient E-W faults at the Oued Lahmar.

This morphometric approach was able to identify the high value of $\mathrm{HI}$ at the level of the watershed $n^{\circ} 37$ as well as the drainage anomalies and the succession of knickpoint revealed at the level of Oued Lahmar watercourse. None of these 


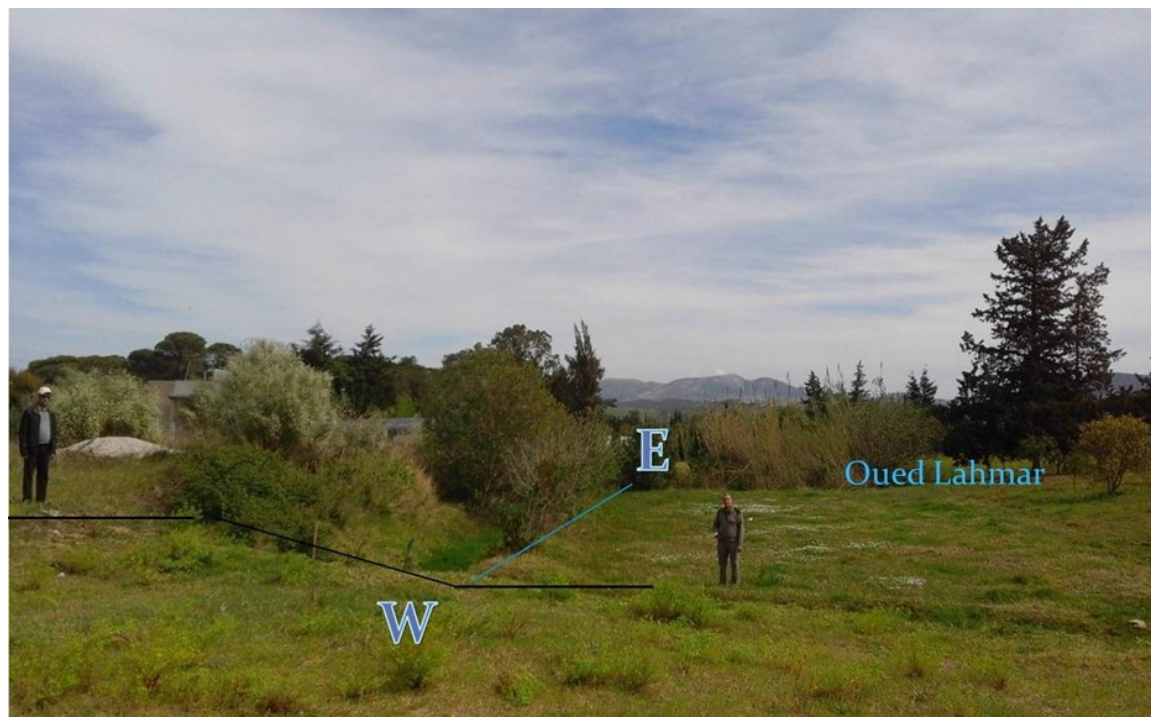

Figure 12. Quaternary terraces on either side of the Oued Lahmar.

observations explained by lithology or by regional tectonics mapped on the geological map.

The absence of any indicator of tectonic lineament at the surface in these basins does not neglect the idea of tectonic control prevailing in them, especially since the cover materials are dominated by old and recent sandstone dunes.

Active faults may not be represented on published geological maps; these are generally based primarily on outcrop fault mapping.

This study revealed the existence of a subsurface tectonic control in Oued Lahmar that is not indicated on the 1:50,000 geological map of the region.

This finding coincides with the results of the aeromagnetic and gravity anomalies analysis performed by Jallouli [49] in the region showing the existence of a deep intrasedimentary igneous body whose length is of the order of $20 \mathrm{~km}$. This E-W tectonic lineament direction follows the most of the magmatic outcrop edge in the Nefza region. Indeed, at the Maghreb region scale, Ben Ayed [32] has described ancient E-W transform faults. This E-W fracturing is deep and it has replayed in dextral strike-slip fault.

\section{Conclusions}

This study focused on the determination of the neotectonic landscape signature of the Oued Lahmar sub watershed, in the North East of Tunisia, based on the morphometric analysis methodology and open sources applications in GIS environment.

Indeed, the use of morphometric indicators especially the spatial distribution of the drainage network anomalies, hypsometric analysis, and knickpoint, coupled with tectonic lineaments data and lithology layers provide a new element in the geological characterization of the region and highlights the existence of masked structural features that remain unknown until today by specifying their trend.

The Oued Lahmar watershed shows clearly an E-W trend tectonic activity. 
This fact is well founded by the hypsometric analysis, the drainage anomalies extraction, the knickpoints identification and the terraced landscape on its watercourse.

This neotectonic activity may be the result of the reactivations of E-W faults well documented in previous studies in the Maghrebides belt region. Therefore, this effect of tectonic stresses and the subsurface thermal phenomenon may allow the intrusion of magma into the sedimentary series and the rejuvenation of these deep faults.

This approach confirms that, in numerous cases, more detailed studies must be conducted at specific geological sites involving precise analysis and investigation of local topography, geology, remote sensing data and fieldwork to better understand local morphology and geology.

The multisource morphotectonic approach presented in this paper provides a basis for neotectonic mapping of the region in the near future.

\section{Conflicts of Interest}

The authors declare no conflicts of interest regarding the publication of this paper.

\section{References}

[1] Horton, R. (1932) Drainage-Basin Characteristics. Transactions, American Geophysical Union, 13, 350-361. http://dx.doi.org/10.1029/TR013i001p00350

[2] Horton, R. (1941) An Approach toward a Physical Interpretation of InfiltrationCapacity. Soil Science Society of America Journal, 5, 399-417. https://doi.org/10.2136/sssaj1941.036159950005000C0075x

[3] Horton, R. (1945) Erosional Development of Streams and Their Drainage Bassins Hydrological Approach to Quantitative Morphology. Bulletin of the Geological Society of America, 56, 275-370. https://doi.org/10.1130/0016-7606(1945)56[275:EDOSAT]2.0.CO;2

[4] Gasparini, N.M., Fischer, G.C., Adams, J.M., Dawers, N.H. and Janoff, A.M. (2016) Morphological Signatures of Normal Faulting in Low-Gradient Alluvial Rivers in South-Eastern Louisiana, USA. Earth Surface Processes and Landforms, 41, 642-657. https://doi.org/10.1002/esp.3852

[5] Saber, R., Isik, V. and Caglayan, A. (2019) Tectonic Geomorphology of the Aras Drainage Basin (NW Iran): Implications for the Recent Activity of the Aras Fault Zone. Geological Journal, 55, 5022-5048. https://doi.org/10.1002/gj.3724

[6] Bhatt, S.C., Singh, R., Ansari, M.A. and Bhatt, S. (2020) Quantitative Morphometric and Morphotectonic Analysis of Pahuj Catchment Basin, Central India. Journal of the Geological Society of India, 96, 513-520. https://doi.org/10.1007/s12594-020-1590-1

[7] Valkanou, K., Karymbalis, E., Papanastassiou, D., Soldati, M., Chalkias, C. and Gaki-Papanastassiou, K. (2020) Morphometric Analysis for the Assessment of Relative Tectonic Activity in Evia Island, Greece. Geosciences, 10, 264. https://doi.org/10.3390/geosciences10070264

[8] Holbrook, J. and Shumm, S.A. (1999) Geomorphic and Sedimentary Response of Rivers to Tectonic Deformation: A Brief Review and Critique of a Tool for Recog- 
nizing Subtle Epirogenic Deformation in Modern and Ancient Settings. Tectonophysics, 305, 287-306. https://doi.org/10.1016/S0040-1951(99)00011-6

[9] Deffontaines, B., Lee, J.-C., Angelier, J., Carvalho, J. and Rudant, J.-P. (1994) New Geomorphic Data on the Active Taiwan Orogen: A Multisource Approach. Journal of Geophysical Research, 99, 20,243-20,266. https://doi.org/10.1029/94JB00733

[10] Smith, M.J., Paron, P. and Griffiths, J.S. (2011) Geomorphological Mapping: Methods and Applications. Volume 15, Elsevier Science, Amsterdam, 610.

[11] Howard, A.D. (1967) Drainage Analysis in Geologic Interpretation: A Summation. Bulletin-American Association of Petroleum Geologists, 51, 2246-3428. https://doi.org/10.1306/5D25C26D-16C1-11D7-8645000102C1865D

[12] Deffonataines, B. (1990) Développement d'une méthodologie morphonéotectonique et morphostructurale; analyse des surfaces enveloppes, du réseau hydrographique et des modèles numériques de terrains; Application au Nord-Est de la France. Thèse, Univ. Paris VI, Paris, 230 p.

[13] Deffontaines, B. and Chorowics, J. (1991) Principles of Drainage Basin Analysis from Multisource Data: Application to the Structural Analysis of the Zaire Basin. Tectonophysics, 194, 237-263. https://doi.org/10.1016/0040-1951(91)90263-R

[14] Deffontaines, B., Chotin, P., Ait Brahim, L. and Rozanov, M. (1992) Investigation of Active Faults in Morocco Using Morphometric Methods and Drainage Pattern Analysis. Geologische Rundschau, 81, 199-210. https://doi.org/10.1007/BF01764549

[15] Ramasamy, S.M., Kumanan, C.J., Selvakumar, R. and Saravanavel, J. (2011) Remote Sensing Revealed Drainage Anomalies and Related Tectonics of South India. Tectonophysics, 501, 41-51. https://doi.org/10.1016/j.tecto.2011.01.011

[16] Bahrami, S. (2013) Analyzing the Drainage System Anomaly of Zagros Basins: Implications for Active Tectonics. Tectonophysics, 608, 914-928.

https://doi.org/10.1016/j.tecto.2013.07.026

[17] Ben Hassene, M., Deffontaines, B. and Turki, M.M. (2014) Semi-Automated Extraction of Drainage Anomalies. Application to the Center of the Southern Atlas of Tunisia. Géomorphologie: Relief, Processus, Environnement, 1, 3-14. https://doi.org/10.4000/geomorphologie.10441

[18] Leeder, M. and Jackson, J. (1993) The Interaction between Normal Faulting and Drainage in Active Extensional Basins, with Examples from the Western United States and Central Greece. Basin Research, 5, 79-102. https://doi.org/10.1111/j.1365-2117.1993.tb00059.x

[19] Comentale, B. (1999) Neotectonique et reseau hydrographique: L'exemple du matese (apennin campanien septentrional, italie)/Neotectonics and Hydrographic Pattern: The Example of the Matese Mountain (Northern Campanian Apennine, Italy). Morfo, 5, 359-373. https://doi.org/10.3406/morfo.1999.999

[20] D’Agostino, N., Jackson, J., Dramis, F. and Funiciello, R. (2001) Interactions between Mantle Upwelling, Drainage Evolution and Active Normal Faulting an Example from the Central Apennines (Italy). Geophysical Journal International, 147, 475-497. https://doi.org/10.1046/j.1365-246X.2001.00539.x

[21] Ferry, M., Meghraoui, M., Karaki, N.A., Al-Taj, M., Amoush, H., Al-Dhaisat, S. and Barjous, M. (2007) A 48-Kyrlong Slip Rate History for the Jordan Valley Segment of the Dead Sea Fault. Earth and Planetary Science Letters, 260, 394-406. https://doi.org/10.1016/j.epsl.2007.05.049

[22] Slama, T. (2008) Conception oriente objet d'un SIG pour l'analyse quantitative morphostructurale et morpho-neotectonique (tectonique active) de la partie nord- 
est de la zone des diapirs, tunisie septentrionale, methode numerique et applications. These de doctorat en geologie, Universite de Tunis El Manar, Faculte des Sciences de Tunis.

[23] Sedrette, S., Rebai, N. and Mastere, M. (2016) Evaluation of Neotectonic Signature Using Morphometric Indicators: Case Study in Nefza, North-West of Tunisia. Journal of Geographic Information System, 8, 338-350.

https://doi.org/10.4236/jgis.2016.83029

[24] Moussi, A. and Rebai, N. (2019) A GIS-Based Tool for Automatic Extraction of Drainage Anomalies. A Case Study of Enfidha (North-East of Tunisia). Geocarto International, 36, 1533-1547. https://doi.org/10.1080/10106049.2019.1655800

[25] Kirby \& Whipple (2012) Expression of Active Tectonics in Erosional Landscapes. Journal of Structural Geology, 44, 54-75. https://doi.org/10.1016/j.jsg.2012.07.009

[26] Perez Pena, J.V. (2009) Gis-Based Tools and Methods for Landscape Analysis and Active Tectonics Evaluation. Master's Thesis, Departamento de Geodinamica, Universidad de Granada, Granada.

[27] Gasparini, N.M. and Whipple, K.X. (2014) Diagnosing Climatic and Tectonic Controls on Topography: Eastern Flank of the Northern Bolivian Andes. Lithosphere, 6, 230-250. https://doi.org/10.1130/L322.1

[28] Giaconia, F., Booth-Rea, G., Martínez-Martínez, J.M., Azañón, J.M., Pérez-Peña, J.V., Pérez-Romero, J. and Villegas (2012) Geomorphic Evidence of Active Tectonics in the Sierra Alhamilla (Eastern Betics, SE Spain). Geomorphology, 145, 90-106. https://doi.org/10.1016/j.geomorph.2011.12.043

[29] Whipple, K. (2004) Bedrock Rivers and Geomorphology of Active Orogens. Annual Review of Earth and Planetary Sciences, 32, 151-185. https://doi.org/10.1146/annurev.earth.32.101802.120356

[30] Castany, G. (1951) Etude géologique de l'Atlas tunisien oriental. Thèse Doctorat ès Sciences: Annales Mines et Géologie, Tunis, 4, 632 p.

[31] Ben Ayed, N. (1986) Evolution tectonique de l'avant-pays alpine de Tunisie. Stratigraphie, caractérestiques géophysiques et évolution géodynamique. Thèse de doctorat, Université de Tunis El Manar.

[32] Ben Ayed, N., Bobier, C. and Viguier, C. (1978) Sur la tectonique récente de la plage du R'Mel, à l'Est de Bizerte (Tunisie Nord-Orientale). Géologie Méditerranéenne, 6, 423-426. https://doi.org/10.3406/geolm.1979.1111

[33] ESRI (2009) GIS Solutions for Urban and Regional Planning "Designing and Mapping the Future of Your Community with GIS”.

[34] Dridri, A. and Fedan, B. (2001) Rôle du contrôle structural dans la mise en place du réseau hydrographique de Sebou et d'Inaouène entre Fès et oued Amlil (Maroc). Bulletin de P Institut scientifique, Rabat, 23, 67-77.

[35] Hack, J.T. (1973) Stream-Profile Analysis and Stream-Gradient Index. Journal of Research of the U.S. Geological Survey, 4, 421-429.

[36] Queiroz, G.L., Salamuni, E. and Nascimento, E.R. (2015) Knickpoint Finder: A Software Tool That Improves Neotectonic Analysis. Computers \& Geosciences, 76, 80-87. https://doi.org/10.1016/j.cageo.2014.11.004

[37] Riazanoff, S. (2001) Extraction et analyse automatiques de réseaux à partir de MNT. Contributions à l'analyse d'images de télédétection. Thèse, Université Paris 7, Paris, $41 \mathrm{p}$.

[38] Jackson, J.A. and Leeder, M. (1994) Drainage Systems and the Development of Normal Faults: An Example from Pleasant Valley, Nevada. Journal of Structural 
Geology, 16, 1041-1059. https://doi.org/10.1016/0191-8141(94)90051-5

[39] Wobus, C., Helmsath, A., Whipple, K. and Hodges, K. (2005) Active Out-of-Sequence Thrust Faulting in the Central Nepalese Himalaya. Nature, 434, 1008-1011. https://doi.org/10.1038/nature03499

[40] Kirby, E. and Ouimet, W. (2011) Tectonic Geomorphology along the Eastern Margin of Tibet: Insights into the Pattern and Processes of Active Deformation Adjacent to the Sichuan Basin. In: Gloaguen, R. and Ratschbacher, L., Eds., Growth and Collapse of the Tibetan Plateau, Geological Society, London, Special Publications Vol. 353, 165-188. https://doi.org/10.1144/SP353.9

[41] Regalla, C., Kirby, E., Fisher, D. and Bierman, P. (2013) Active Forearc Shortening in Tohoku, Japan: Constraints on Fault Geometry from Erosion Rates and Fluvial Longitudinal Profiles. Geomorphology, 195, 84-98.

https://doi.org/10.1016/j.geomorph.2013.04.029

[42] Harvey, A.M., Miller, S.Y. and Wells, S.G. (1995) Quaternary Soil and River Terrace Sequences in the Aguas/Feos River Systems: Sorbas Basin, SE Spain. In: Lewin, J., Macklin, M.G. and Woodward, J.C., Eds., Mediterranean Quaternary River Environments, A. A. Balkema, Rotterdam, 263-281.

[43] Mather, A.E., Stokes, M. and Griffiths, J.S. (2002) Quaternary Landscape Evolution: A Framework for Understanding Contemporary Erosion, SE Spain. Land Degradation \& Management, 13, 1-21. https://doi.org/10.1002/ldr.484

[44] Stokes, M., Mather, A.E. and Harvey, A.M. (2002) Quantification of River Capture Induced Base-Level Changes and Landscape Development, Sorbas Basin, SE Spain. Geological Society of London Special Publication, 91, 33-55. https://doi.org/10.1144/GSL.SP.2002.191.01.03

[45] Westaway, R., Bridgland, D. and White, M. (2006) The Quaternary Uplift History of Central Southern England: Evidence from the Terraces of the Solent River System and Nearby Raised Beaches. Quaternary Science Reviews, 25, 2212-2250. https://doi.org/10.1016/j.quascirev.2005.06.005

[46] Westaway, R. and Bridgland, D.R. (2010) Causes, Consequences and Chronology of Large-Magnitude Palaeoflows in Middle and Late Pleistocene River Systems of Northwest Europe. Earth Surface Processes and Landforms, 35, 1468-1479. https://doi.org/10.1002/esp.1968

[47] Westaway, R. and Bridgland, D.R. (2014) Relation between Alternations of Uplift and Subsidence Revealed by Late Cenozoic Fluvial Sequences and Physical Properties of the Continental Crust. Boreas, 43, 505-527. https://doi.org/10.1111/bor.12051

[48] Bridgland, D., Westaway, R. and Cordier, S. (2009) Les causes de l'étagement des terrasses alluviales à travers le monde. Factors Affecting the Worldwide Development of Long-Timescale Fluvial Terrace Staircases. Quaternaire, 20, 5-23. https://doi.org/10.4000/quaternaire.4994

[49] Jallouli, C., Inoubli, M.H. and Albouy, Y.Y. (1996) Le corps igné de Nefza (Tunisie septentrionale): Caractéristiques géophysiques et discussion du mécanisme de sa mise en place. Notes du service Géologique de Tunisie, No. 62, 109-123. 